\title{
THE IMPLEMENTATION OF ISLAMIC EDUCATION TEACHING AT INCLUSIVE SCHOOLS IN SAMARINDA, EAST KALIMANTAN
}

\author{
Fitra Elnurianda', Umar Fauzan², Syeh Hawib Hamzah³ \\ ${ }^{1,2,3}$ State Institute for Islamic Studies (IAIN) Samarinda \\ Jl. H. A. M Rifaddin Harapan Baru, Samarinda, East Kalimantan, Indonesia \\ E-mail: fitraelnur@gmail.com; dr.umarfauzan@gmail.com; hamzahsahilgo@gmail.com
}

\begin{abstract}
The Implementation of Islamic Education Teaching at Inclusive Schools in Samarinda, East Kalimantan. Education is an individual right for all citizens, including children with special needs. The objective of the research is to describe the implementation of Islamic education teaching at inclusive schools in Samarinda. This research is a qualitative research using phenomenology approach conducted at elementary schools (SD) in Samarinda; SD Fastabiqul Khairat Samarinda, SD Bunga Bangsa Samarinda, and State Elementary School (SDN) 016. The techniques used in data collection are observation, interview, and documentation. The data was analyzed by using the interactive model by Miles and Huberman. The finding of this research reveals that the implementation of Islamic education teaching at inclusive schools in Samarinda requires several adjustments in teaching planning, implementation process, and learning evaluation. Those adjustments were created in the form of special class, by providing specific time allocation, preparing different teaching materials, applying different teaching methods, and using a mixed approach.
\end{abstract}

Keywords: Islamic education teaching; inclusive schools; class management; special need.

\begin{abstract}
Abstrak: Implementasi Pengajaran Pendidikan Islam pada Sekolah Inklusi di Samarinda, Kalimantan Timur. Pendidikan adalah hak setiap warga negara, termasuk individu yang berkebutuhan khusus.Tujuan dari penelitian ini adalah untuk mendeskripsikan implementasi dari pendidikan agama Islam sekolah inklusi di Samarinda. Penelitian yang digunakan dalam artikel ini adalah penelitian kualitatif fenomenologi yang dilaksanakan di Sekolah Dasar (SD) di Samarinda; SD Fastabiqul Khairat Samarinda, SD Bunga Bangsa Samarinda, dan Sekolah Dasar Negeri (SDN) 016.Teknik pengumpulan data menggunakan wawancara, observasi, dan dokumentasi. Analis data menerapkan model Interaktif Miles dan Huberman. Hasil penelitian menunjukkan bahwa implementasi pendidikan Islam sekolah inklusi di Samarinda memerlukan beberapa penyesuaian dalam hal perencanaan pengajaran, proses pengajaran, dan evaluasi pengajaran. Beberapa penyesuaian tersebut antara lain adalah: penyediaan kelas khusus, penyedian alokasi waktu khusus, penyiapan berbagai variasi bahan ajar, penerapan metode pengajaran yang berbeda dengan kelas reguler, dan penggunaan model beberapa campuran pendekatan pengajaran.
\end{abstract}

Kata kunci: pengajaran pendidikan Islam; sekolah inklusi; manajemen kelas; kebutuhan khusus.

\section{Introduction}

Teaching for exceptional children has been treated equally important in educational system in Indonesia. Data from the Ministry of Education and Culture showed that the number of children with special needs in Indonesia has reached 1.6 million. Out of 1.6 million children with special needs only 18 percent that had received inclusive educational services. Approximately, there are 115 thousand children with special needs attend school in the schools for special need students, while the children with special needs who attend inclusive school are about 299 thousand. ${ }^{1}$ Cartwright in Astuti, et. al, as quoted by Syafrida Elisa and Aryani Tri Wrastari mentioned the purpose of inclusive education is a practice that aims to fulfill the human rights of education without discrimination, by providing

${ }^{1}$ Kementerian Pendidikan dan Kebudayaan, "Sekolah Inklusi dan Pembangunan SLB Dukung Pendidikan Inklusi", in https:// www.kemdikbud.go.id/main/blog/2017/02/sekolah-inklusi-danpembangunan- slb-dukung-pendidikan-inklusi, accessed March 27, 2018. 
quality educational opportunities to all children without exception, so that all children have equal opportunity to actively develop their personal potential in the same environment. ${ }^{2}$

Empirical facts though, teachers who teach in inclusive schools still give different treatment to children with special needs, and sometimes they still feel burdened in teaching them. Teachers perform a significant role in the implementation of teaching programs that must be adjusted to the child's abilities. Especially in the inclusive education, the ability of students with special needs is different from the normal students. The educational principle adjusted in inclusive schools led to a skillful demand for regular teachers as well as special needs education teachers. They have a common task to adapt the learning environment to the needs and abilities of each student in the classroom.

Islamic education has been taught in inclusive schools in Indonesia. Islamic education at inclusive school Sukoharjo runs by using two regular curriculum, which are Curriculum 2013 and Inclusion Curriculum that has been modified. In the process of Islamic education teaching, the teachers work together with shadow/companion teachers who guide and provide explanations to children with special needs. ${ }^{3}$ Inclusive schools in Malang uses Curriculum 2013 with individual learning program but the material is simplified according to the ability of children with special needs. ${ }^{4}$ Inclusive school in Medan uses National Curriculum of Government adapted to the ability of children with special needs in an Individual Education Plan (IEP). ${ }^{5}$

${ }^{2}$ Syafrida Elisa and Aryani Tri Wrastari, "Sikap Guru Terhadap Pendidikan Inklusi Ditinjau dari Faktor Pembentuk Sikap”, Jurnal Psikologi Perkembangan dan Pendidikan Universitas Airlangga, No. 01, February II 2013, p. 3.

${ }_{3}^{3}$ Desi Kurniasari, Evaluasi Program Pembelajaran PAI Pada Pendidikan Inklusif di Sekolah Menengah Al Firdaus Sukoharjo, (Surakarta: IAIN Surakarta, 2017), pp.58-60.

${ }^{4}$ Alfin Nurussalihah, Implementasi Pembelajaran Pendidikan Agama Islam Terhadap Anak Berkebutuhan Khusus di Sekolah Inklusi Studi Multisitus di SDN Mojorejo 01 dan SDN Junrejo 01 Kota Batu, (Malang: Universitas Islam Negeri Maulana Malik Ibrahim, 2016), p.116-119.

${ }_{5}$ Raudho Zaini, Implementasi Pembelajaran Pendidikan Agama Islam Pada Anak Berkebutuhan Khusus di Sekolah Alam Medan, (Medan: Institut Agama Islam Negeri Sumatera Utara, 2013), p.35.
Therefore, Islamic education in Indonesia is incorporated in the National Curriculum. Religious education is a foundational thing that must be given to all learners as a provision of life. The embodiment of religion in school is summarized in Islamic education subjects, which must be followed by all learners ranging from elementary to university. Formation of good attitudes and habits are shown and compiled by providing a correct understanding of religious education. With the correct understanding of religion, it is expected that the students with special needs will have spiritual strength, self-control, personality, intelligence, noble character and skills needed by society, nation, and state. ${ }^{6}$

A good teaching requires careful planning and in its implementation involves various parties, both teachers and students. In order to make the teaching process run effectively and efficiently, it is necessary to make a teaching program. The teaching program is a guide for teachers in implementing Islamic education. The teaching of children with special needs combined the program from regular classes and special attention. The teachers can make teaching plans to be different from expected goals and competencies. Children with special needs should get the same rights in learning Islamic education despite of their limitations.

According to Zakiah Darajat, the growth of the sense of religiousness in children has begun since birth and that was what he brought the first time when he went to school.? In the book titled Development of Religious Experience in Children written by Ernest Harms, at the level of the realistic stage, the child goes to elementary school at the age of adolescence, the idea of the divine on the child already reflects the concepts that are based on fact or reality. This concept arises through religious institutions and teaching from adults. Based on this theory, the children took interest and pleased to see their religious institution managed by the adults in their environment, so that all religious action would

\footnotetext{
6 Muhaimin, Paradigma Pendidikan Islam, (Bandung: Remaja Rosdakarya, 1996), pp.1-2.

7 Zakiah Darajat, Ilmu Jiwa Agama, (Jakarta: Bulan Bintang, 1970), p.111.
} 
be followed and studied with great significance. ${ }^{8}$

In fact, the teaching process has not been implemented properly because a set of requirement for teaching sometimes has not fulfilled. Amin Haedari states that adequate learning resource has not supported the teaching of Islamic education and lack of teaching materials. There are still many teachers of Islamic education who do not have Islamic education background because there hasn't been a study program or majors of Islamic religious in colleges/ universities specializing in education for special need learners. ${ }^{9}$

Studies have been conducted to describe the teaching of children with special needs; Nurussalihah (2016) investigated the lesson plan in inclusion class $^{10}$, Mayasari (2016) focused on the implementation of Curriculum 2013 toward children with special needs"11, Hermawati (2015) studied the implementation of Islamic religious models for children with special needs ${ }^{12}$, Zaini (2013) tried to explain the implementation of Islamic education learning on children with special needs in sekolah alam ${ }^{13}$, and Marzuenda (2013) researched the implementation of Islamic education learning at extraordinary school. ${ }^{14}$

In Samarinda where this study was conducted, there are still some schools, especially primary schools that do not receive special needs children to get the same education as other normal children. Researchers find it difficult to find out which schools are holding inclusive education

\footnotetext{
${ }^{8}$ Ernest Harms, The Development of Religious Experience in Children, (Chicago: The University of Chicago Press, 1994), pp. 112-122.

9 Kementerian Agama Republik Indonesia, "Kemenag Siapkan Bahan Ajar PAI Untuk Anak Berkebutuhan Khusus", in https://www2.kemenag.go.id/berita/152833/kemenag-siapkanbahan-ajar-pai-untuk-anak-berkebutuhan-khusus, accessed February 4, 2018.

${ }^{10}$ Alfin Nurussalihah, Implementasi Pembelajaran..., p.23.

1 Mayasari, Implementasi Kurikulum 2013 Pada Anak Berkebutuhan Khusus (ABK) di SD Muhammadiyah Sapen Yogyakarta, (Yogyakarta: Universitas Islam Negeri Sunan Kalijaga, 2016), p.9.

12 Hermawati, Penerapan Model Pembelajaran Agama Islam Bagi Anak Berkebutuhan Khusus di Sekolah Dasar Negeri 016 Kecamatan Sungai Kunjang Kota Samarinda, (Samarinda: Institut Agama Islam Negeri, 2015), p.6.

${ }^{13}$ Raudho Zaini, Implementasi Pembelajaran..., p.28.

${ }^{14}$ Marzuenda, Pelaksanaan Pembelajaran Pendidikan Agama Islam di Sekolah Luar Biasa Sri Mujinab Pekanbaru, (Pekanbaru: Universitas Islam Negeri Sultan SyarifKasim, 2013), p.11.
}

among 246 Primary Schools/ Madrasah Ibtidaiyah, 113 Middle Schools/Madrasah Tsanawiyah and 103 Senior Schools/ Vocational Schools/ Madrasah Aliyah (June 2014) because Education and Culture Office in Samarinda does not yet have accurate and specific data. ${ }^{15}$ Until 2017 in Samarinda there are three elementary schools that broadly known provide inclusive education programs and have a decision letter/Surat Keputusan from the education departments/ Dinas Pendidikan to organize inclusive education, SD Fastabiqul Khairat Samarinda, SD Bunga Bangsa Samarinda, and SDN 016 Samarinda. In these schools the researcher is concerned to conduct research in the implementation of Islamic Education Teaching in children with special needs in three of these inclusive schools, because children with special needs are individuals with personal uniqueness.

\section{Method}

This research used qualitative research method with phenomenological approach. This research is focused on the implementation of Islamic education teaching. The main instrument of the research is the researchers. The data sources for this study were people who are considered to be part of the process and have information about the implementation of Islamic education teaching. The selected schools are SD Fastabiqul Khairat Samarinda, SD Bunga Bangsa Samarinda, and SDN 016 Samarinda, since those three elementary schools are officially known providing inclusive education programs. In data collection, the researcher used observation, interview, and documentation. The collected data was analyzed by using the interactive model of Miles and Huberman ${ }^{16}$.

\section{Teaching Planning}

Teaching planning is the process of composing the learning program that becomes the reference and the implementation pattern of teaching for

${ }^{15}$ Pemerintah Provinsi Kalimantan Timur Dinas Pendidikan dan Kebudayaan, “Rekap Data JumlahSekolah Data Juni 2014”, in http://disdik.kaltimprov.go.id/pages/statis/28/rekap-data-jumlahsekolah.html, accessed March 25, 2018.

${ }^{16}$ Miles dan Huberman, Analisis Data Kualitatif, (Jakarta: Universitas Indonesia Press, 1992) p.20. 
teachers. In Islamic education, teachers prepared all the planning documents such as syllabus, lesson plan for semester and annual program. The planning in inclusive schools is prepared by Islamic education teachers. The teacher, as respondent 2, of SD Fastabiqul Khairat Samarinda in an interview said:

"I prepare the teaching materials, then the core competence, the basic competence that we have to know in order to facilitate the teaching strategies to the children, the teaching materials are also prepared with the lesson plans and the syllabus. There is no difference between Islamic education lessons in inclusion classes and regular classes. ${ }^{7}$ "

According to the result of SD Fastabiqul Khairat Samarinda documentation data from the teachers' documents, the researcher only found 2 respondents who prepared all teaching planning documents such as syllabus, lesson plan for semester and annual program. Other teachers were still using another school's teaching planning documents and adjusted the change according to the class situation only when it was implemented.

Related to teaching planning, the school principal of SD Bunga Bangsa Samarinda in an interview said that for inclusive class, one student with special needs has 1 lesson plan. So if in the class there are 3 children with special needs then the teacher should prepare 3 lesson plans according to the student's ability..$^{18}$ From documentation of SD Bunga Bangsa Samarinda, the researcher found that there was no teaching planning documents such as syllabus, lesson plan for semester and annual program. Based on the situation in the field, teaching planning documents of inclusive class for children with special needs had not been provided by the teachers; the teachers only prepared worksheets for each child.

In SDN 016 Samarinda related to teaching planning, inclusive class coordinator in an interview said that they had a general program, and individual

${ }^{17}$ Interview with Muhammad Rahman, Islamic education teacher R2 of Fastabiqul Khairat Elementary School Samarinda, April 2, 2018.

${ }^{18}$ Interview with Yeny Duwi Seviawati, School Principal of Bunga Bangsa Elementary School Samarinda, April 11, 2018. programs were adjusted per class. ${ }^{19}$ The teacher of SDN 016 Samarinda in an interview said:

"Honestly I do not provide lesson plan for inclusion class. Islamic education lessons in inclusion classes and regular classes is clearly different, in terms of learning materials alone is different. For children with special needs in inclusion class, the material in the syllabus should be simplified. The most important thing is knowing which grade that I have to teach tomorrow, the characters of the learners and the material that I have to teach. ${ }^{20 "}$

By figuring out the teachers' documents of SDN 016 Samarinda, the researcher found that there are no teaching planning documents such as syllabus, lesson plan for semester and annual program. Based on the fact in the field, teaching planning documents of inclusive class for children with special needs had not been provided by Islamic education teacher. The teaching preparation was only about the material to be taught on that day and the implementation of Islamic education teaching is not accompanied by a lesson plan document.

\section{Curriculum}

Before preparing the teaching implementation, the teacher must know the curriculum used in the inclusive class. The curriculum is one of the most important components in the learning process. The curriculum serves as a guide in learning. Hence, the goals to be achieved can be realized. In inclusive schools the curriculum adapts the children with special needs. Curriculum at SD Fastabiqul Khairat Samarinda as stated by school principal in an interview:

"We are using the government curriculum, the Curriculum 2013. It's just that for children with special needs, the delivery of the material is slightly different from regular children. The reason is that the Curriculum of 2013 approach is scientific. ${ }^{21}$ "

\footnotetext{
19 Interview with Nurhaemi, Inclusion Coordinator of 016 Public Elementary School Samarinda, April 24, 2018.

${ }^{20}$ Interview with Anni Rosydah, Islamic Education Teacher of 016 Public Elementary School Samarinda, April 24, 2018..

${ }^{21}$ Interview with Rasyanto, School Principal of Fastabiqul Khairat Elementary School Samarinda, April 4, 2018.
} 
In the observation of the teaching at SD Fastabiqul Khairat Samarinda, the researcher found that the teachers taught the students with special needs slightly different from other regular students in the delivery of material, they had to re-explain the material to the children with special needs individually if they do not have shadow teacher next to them. The teacher asked the students about the material to make sure that the companion teacher re-explains the material correctly. ${ }^{22}$ The documentation of SD Fastabiqul Khairat Samarinda shows that SD Fastabiqul Khairat Samarinda was applying the Curriculum of 2013.23

Furthermore, curriculum used at SD Bunga Bangsa Samarinda according to head of Inclusion unit in an interview:

"We still use the school-based curriculum, because it is simpler according to students' ability. We have to adjust it in class. Therefore in inclusive class we do not use textbooks, we have our own worksheet that has been adapted to the ability of the child. ${ }^{24 "}$

Supporting that statement, the school principal in an interview said that modification made in the lesson plan. Therefore, in inclusive class one student with special needs has 1 lesson plan. If in the class there are 3 children with special needs, then the teacher should prepare 3 lesson plans according to the student's ability. ${ }^{25}$ The teacher stated that SD Bunga Bangsa Samarinda used the school-based curriculum. ${ }^{26}$ The result of observation of SD Bunga Bangsa Samarinda shows that the teacher had to re-explain the material to the children with special needs individually adjusting to their special needs. ${ }^{27}$ Not only by the interview and observation, the researcher also checked the documentation. From the result of documentation, the researcher found

${ }^{22}$ Interview with Rasyanto, School Principal of Fastabiqul Khairat Elementary School Samarinda, April 4, 2018.

${ }^{23}$ Document data of Fastabiqul Khairat Elementary School Samarinda, Curriculum Document 12017 from School Principal.

${ }^{24}$ Interview with Eka Sri Muliani, Head of Inclusion Unit of Bunga Bangsa Elementary School Samarinda, March 23, 2018.

${ }^{25}$ Interview with Yeny Duwi Seviawati, School Principal of BungaBangsa Elementary School Samarinda, April 11, 2018.

${ }^{26}$ Interview with Adimah Kasim, Islamic Education Teacher of Bunga Bangsa Elementary School Samarinda, April 9,2018.

27 Observation in Bunga Bangsa Elementary School Samarinda, April 9, 2018 and during a visit in March to May 2018. that the school was applying the school-based curriculum. $^{28}$

Curriculum used in SDN 016 Samarinda according to the statement of Inclusive teaching Coordinator in an interview was:

"The curriculum refers to the regular class curriculum. There are The School-Based Curriculum and Curriculum 2013, but our school modifies the curriculum by ourselves for children below the average as proper as we can. So in this school we have a special individual program, Special Lesson Plan and as well modified curriculum. ${ }^{29}$ "

Based on the result of observation at SDN 016 Samarinda, the researcher found that the teacher had to decrease the difficulty level of the lesson to the children with special needs individually. ${ }^{30} \mathrm{According}$ to the result of documentation data from administration staff, the researcher found that the school was applying two curriculums, Curriculum of 2013 in grade 1, 2, 4 and 5, and the school-based curriculum in grade 3 and $6 .{ }^{31}$

\section{Classroom Management}

Classroom management is an effort to manage students in the classroom to create and maintain a classroom atmosphere that supports the teaching program by creating a fun atmosphere and maintaining the motivation of students to always be involved and participate in the education process in school. The schools provide a special and mixed classroom with different types of special needs in a various sitting position.

From the interview and observation at SD Fastabiqul Khairat Samarinda, the researcher found that children with special needs were sitting with a companion teacher. The sitting position was facing forward and sideways in

${ }_{28}$ Document data of Bunga Bangsa Elementary School Samarinda, Curriculum Document 12017 from School Principal.

29 Interview with Nurhaemi, Inclusion Coordinator of 016 Public Elementary School Samarinda, April 24, 2018.

${ }^{30}$ Observation in 016 Public Elementary School Samarinda, Samarinda Monday, May 14, 2018 and during a visit in March to May 2018.

31 Document data of 016 Public Elementary School Samarinda, Curriculum 016 Public Elementary School Samarinda 2017-2018 School Year from Administration Staff 
random rows. In the class, there were 1-2 children with special needs in different types. Usually they learned in the same class with other student but when the children with special needs are in the mood to learn outside their classroom, they can use Counseling Room to study or do any activities. ${ }^{32}$ From the result of documentation data, the researcher found that in grade 1 there are 3 students with Cerebral Palsy, Slow Learner and Down Syndrome, in grade 2 there are 3 students with Slow Learner, in grade 3 there is 1 student with Down Syndrome, in grade 4 there are 2 students with Slow Learner, and in grade 5 there is 1 student with Slow Learner. ${ }^{33}$

From the interview and observation at SD Bunga Bangsa Samarinda, the researcher found that children with special needs were learning in the special room and were sitting in front of the teacher and the companion teacher was behind them. There were five children with various types of special needs in the class. The sitting position was facing forward in letter U-shape. In the room, students sat with a study table without chairs. The companion teachers were helping them to read, write and also accompany them when they need to go to the toilets. ${ }^{34}$ According to the result of documentation at SD Bunga Bangsa, the researcher found that in 1st grade there are 3 students with Attention-deficit/Hyperactivitydisorder (ADHD), Autism and learning disabilities, in 2 nd grade there are 2 students with learning disabilities and Deafness, in 3rd grade there are 5 students with Cerebral Palsy, Deafness, Slow Learner, and in 4th grade there are 2 students with Autism and Slow Learner. ${ }^{35}$

From the interview and observation at SDN 016 Samarinda, the researcher found that children with special needs were learning in the same room, the sitting position was facing forward

${ }^{32}$ Observation in FastabiqulKhairat Elementary School Samarinda, Samarinda Wednesday, April $4^{\text {th }} 2018$, Thursday, April $5^{\text {th }} 2018$, Tuesday, April $10^{\text {th }} 2018$ and during a visit in March to May 2018.

${ }^{33}$ Document data of Fastabiqul Khairat Elementary School Samarinda, Student data from Administration Staff 2017.

34 Observation in Bunga Bangsa Elementary School Samarinda, Samarinda Friday, April 9, 2018 and during a visit in March to May 2018.

35 Document data of Bunga Bangsa Elementary School Samarinda, Student data from Head of Inclusion Unit 2017. in rows. There were 17 students with various types of special needs. ${ }^{36}$ From the result of documentation data, the researcher found that in grade 1 there are 8 students, in grade 2 there are 17 students, in grade 3 there are 11 students, in grade 4 there are 10 students, in grade 5 there are 8 students and in grade 6 there are 15 students. ${ }^{37}$

\section{Time Allocation}

Time allocation is needed to know how many hours of effective time available to be utilized in the learning process within one academic year and so that all basic competencies present in the curriculum can all be achieved by the students. The schools provide various time allocations. Time allocation in inclusive class at SD Fastabiqul Khairat Samarinda according to the teacher, as respondent 2, in an interview:

"In class we equate the time $2 \times 30$ Minutes. There is no difference from the regular class. ${ }^{38}$ "

From the observation at SD Fastabiqul Khairat Samarinda, the researcher found that the time allocation was $2 \times 35$ minutes. ${ }^{39}$ According to the result of documentation at SD Fastabiqul Khairat Samarinda, the researcher found that the time allocation in that class was $2 \times 35$ minutes once a week. ${ }^{40}$

For time allocation in inclusive class at SD Bunga Bangsa Samarinda, the teacher in an interview stated that the time allocation for teaching in the inclusive class was $2 \times 30$ minutes. Grades 1 and 2 are conjoined and Grade 3 and 4 are conjoined in the same class. According to the interview of the teacher in SD Bunga Bangsa

${ }^{36}$ Observation in 016 Public Elementary School Samarinda, Samarinda Monday, May 142018 and during a visit in March to May 2018.

37 Document data of 016 Public Elementary School Samarinda, Student data from Administration Staff 2017.

${ }^{38}$ Interview with Muhammad Rahman, Islamic Education Teacher R2 of Fastabiqul Khairat Elementary School Samarinda, April 2, 2018.

39 Observation in Fastabiqul Khairat Elementary School Samarinda, Samarinda Wednesday, April 4 2018, Thursday, April 5. 2018, April 10, 2018 and during a visit in March to May 2018.

40 Document data of Fastabiqul Khairat Elementary School Samarinda, teaching schedules $2^{\text {nd }}$ semester 20172018 academic year from Administration Staff. 
Samarinda, the time allocation for teaching in the inclusive class was $2 \times 30$ minutes. ${ }^{41} \mathrm{From}$ the observation, the researcher found that the time allocation for teaching and learning was $2 \times 30$ minutes..$^{42}$ According to the result of documentation at SD Bunga Bangsa Samarinda, the researcher found that the time allocation for teaching and learning in inclusive class was $2 \times 30$ minutes once a week for grade 1 and 2 as well as for grade 3 and 4.43

From the observation at SDN 016 Samarinda, the researcher found that the time allocation in inclusive class was $3 \times 35$ minutes..$^{44}$ According to the result of documentation at SDN 016 Samarinda, the researcher found that the time allocation for teaching in inclusive class was $3 \times 35$ minutes once a week. ${ }^{45}$

Based on the all above information, the time allocation of Islamic education lesson in the inclusion class at SD Fastabiqul Khairat Samarinda was 2x 35 minutes once a week, while at SD Bunga Bangsa Samarinda was $2 \times 30$ minutes once a week, and at SDN 016 Samarinda was $3 \times 35$ minutes once a week. However, in the practice, the time allocation could be less than that because the teacher has to face unexpected circumstances from the children with special needs.

\section{Teaching Materials}

The materials specified for the learning activities should be materials that support the process of achievement of basic competence and standard competency, and the achievement of indicators.

Based on the collected data from the

${ }^{41}$ Interview with Adimah Kasim, Islamic Education Teacher of Bunga Bangsa Elementary School Samarinda, April 9, 2018.

42 Observation in Bunga Bangsa Elementary School Samarinda, Samarinda Friday, April 9, 2018 and during a visit in March to May 2018.

43 Document data of Bunga Bangsa Elementary School Samarinda, teaching schedules $2^{\text {nd }}$ semester $2017-2018$ academic year from Head of Inclusion Unit.

44 Observation in Bunga Bangsa Elementary School Samarinda, Samarinda Friday, April 9,2018 and during a visit in March to May 2018.

45 Document data of 016 Public Elementary School Samarinda, teaching schedules $2^{\text {nd }}$ semester 2017-2018 academic year from Administration Staff. interview, observation, and documentation, the researcher found that at SD Fastabiqul Khairat, the materials of Islamic Education related to faith (akidah), worship (ibadah), morals (akhlak), and the pillars of faith, such as asmâ'ul husnâ, praise worthy character, prayer, dhikr, the story of the prophets and the life of Wali Songo. ${ }^{46}$

Based on the collected data from SD Bunga Bangsa Samarinda, the researcher found that the materials of Islamic education in the inclusive class for grade 1 and 2 the material being taught were about short surah in the Quran, the content of ayat in the Quran, daily eating and drinking manners or adab and for grade 3 and 4 the material being taught were about tauhîd or oneness of God, asmâ'ul husnâ, good characteristics, praiseworthy behavior or akhlak, loving animals and taking care of the environment. ${ }^{47}$

At SDN 016 Samarinda, Islamic education materials according to the result of the interview, observation, and documentation, it was found that the materials of Islamic education in the inclusion class were different from the learning materials in regular class. Learning materials were related to the Quran, faith, worship, morals, the pillars of faith, the introduction about Allah, malaikat, good deeds. The materials always has connecting with their daily lives. ${ }^{48}$

\section{Teaching Approach and Teaching Method}

Based on the interview to the teachers at SD Fastabiqul Khairat Samarinda, the researcher found that the teachers have multiple attraction and strategies to pay more attention to children with special needs. The approach used by the teachers to teach Islamic education is Mixed Approach. There is no difference in teaching methods between regular children and children with special needs. The teachers coordinate more with the companion teachers in the classroom. The teachers are free in determining

${ }^{46}$ Interview with Muhammad Rahman, Islamic Education Teacher R2 of Fastabiqul Khairat Elementary School Samarinda, April 2,2018.

47 Interview with Adimah Kasim, Islamic Education Teacher of Bunga Bangsa Elementary School Samarinda, April 9, 2018.

${ }^{48}$ Interview with Anni Rosydah, Islamic Education Teacher of 016 Public Elementary School Samarinda, April 24, 2018. 
the appropriate learning methods in Islamic education. The teacher might uses Discussion Method, Demonstration Method, Lecturing Method, Storytelling, Recitation Method, Practical Method, Question-Answer Method, Advising, and Customizing. The teacher connected the lesson to the students' daily life experiences. From the observation at SD Fastabiqul Khairat Samarinda, the researcher found that the teachers were using Lecturing Method, The Story of Quran and Prophet and Question-Answer Method. The teacher used Mixed Approach. ${ }^{49}$ The researcher did not find any documents related to the teaching approach and teaching method. So, there is no information related to the teaching approach and teaching method from the documentation.

Based on the information from interview at SD Bunga Bangsa Samarinda, it was found that the teaching begun with the classical method but at the time of the learning process run the teacher used more individual approach. In contrast to regular classroom learning, the inclusion classes used simplified words so that they are easy to understand, the explanation is purposed into each child individually. The teacher used different methods to each child according to their type of special needs. The school gave a freedom to the teachers in determining the appropriate teaching methods to teach the students. Teaching methods are varied according to the type of children with special needs, grade levels and other circumstances. The teacher used Lecturing Method, The Story of Quran and Prophet, Recitation Method, Practical Method, Question-Answer Method, Advising, and daily life experience-connected method. From the observation at SD Bunga Bangsa Samarinda, the researcher found that the teacher used through Lecturing Method, Recitation Method, Through Advice and Question-Answer Method. The teacher used Individual Approach. At SD Bunga Bangsa Samarinda, the researcher did not find any documents related to the teaching approach and teaching method.

49 Observation in Fastabiqul Khairat Elementary School Samarinda, Samarinda Wednesday, April 4, 2018, Thursday, April 5, 2018, April 10, 2018 and during a visit in March to May 2018.
Related to the teaching approach and teaching method at SDN 016 Samarinda, the result of interview and observation showed that the teacher used an individual approach because they think treating children with autism and children with learning disabilities is different. Teaching methods used by the teacher were varied such as through The Story of Quran and Prophet, through Advice, through Custom and By Exemplary or Direct Practice and relate it to their daily life experience. The teacher adjusted the material and the situation at that time because the children with special needs depend on the state of their mood.

\section{Learning Evaluation}

Based on the information taken from SD Fastabiqul Khairat Samarinda, it could be figured out that in learning evaluation for children with special needs, the teachers determined their own aspects to be assessed from children with special needs in accordance with their ability. There are teachers who assess the affective aspect only as long as they show good behavior. There are also teachers who assess all aspects of cognitive, psychomotor and affective depending on the basic competence. Evaluation was given in the form of test questions that have been adapted according to the ability of children with special needs. There was also a practical assessment and assessment of skills following the materials that had been taught. For the mid test and the final exam of the semester, the school provided pre-test questions according to the ability of children with special needs to determine the ability of children with special needs. The score for minimum passing grade is 75. If a student with special needs was able to pass the score, the school would give him/her the regular test questions. If he was not able to follow through, he/she would have special test questions created by the teachers. Then, if a student still could not reach the minimum passing grade, the teacher would do remedies in the form of easier questions. Report on learning outcomes was in the form of scores value and by a narrative description related to students' development. 
Learning evaluation at SD Bunga Bangsa Samarinda, based on the collected data from the interview, observation, and documentation, it was found that the aspects that evaluated from children with special needs in inclusive class were their level of understanding, behavior, worship and daily life practice. The assessment is taken from the question and answer process both oral and written worksheet. In the mid test and the final exam of the semester, the school provided test questions. The minimum passing grade is 75 . Report on learning outcomes was in the form of scores value and a narrative description related to students' development. For the national exam there are two paths; the school exams and the national exam.

At SDN 016 Samarinda, learning evaluation was done in the end of each meeting; the teacher gave an evaluation by oral question. For the mid test and the final exam of the semester, the school provided test questions. The score was based on school curriculum for grade 3 and 6 and Curriculum of 2013 for grade 1, 2, 4 and 5 . The minimum passing grade score is 70 . Related to the national examination, there were several methods for students with special needs. The system varied according to the provisions of the Department of Education the year the exam was taken, some might take part in the National Examination and some might take School Examination. So far for the National Examination, there were no special test questions for students with special needs, thus they had to answer test questions for the regular student.

\section{The Application of Islamic Education Teaching in Inclusive Shcool in Samarinda}

The researcher found that the teaching planning at SD Fastabiqul Khairat Samarinda, SD Bunga Bangsa Samarinda, and SDN 016 Samarinda compared to the theory of experts, the Regulation of the National Ministry of Education Number 70 Year 2009, and several previous researches are similar. The teachers know that they are the ones who are devising the teaching planning and considering the individual differences in children with special needs.

According to the research findings, the school curriculum in inclusive class at SD Fastabiqul Khairat Samarinda applied Curriculum of 2013, SD Bunga Bangsa Samarinda applied the schoolbased curriculum, and SDN 016 Samarinda applied both curriculum at different grade level, grade 1, 2, 4 and 5 applying Curriculum of 2013 and grade 3 and 6 applying the school-based curriculum. At SD Fastabiqul Khairat Samarinda, the curriculum modifications are contained in the delivery of material that slightly different from regular class as well as the level of difficulty of the test questions are adjusted. At SD Bunga Bangsa Samarinda and SDN 016 Samarinda, the curriculum is modified in the lesson plan and the difficulty level of the lesson. The teaching model and the material are being simplified, so that the curriculum adapts the children with special needs.

According to Asep Supena, in 42 inclusive primary schools and 3 special schools (in DKI Jakarta, Bogor, Bogor District, Pandeglang and Bandung District), 40 non-inclusive primary schools (in Bangka Belitung, Jambi, Aceh, South Kalimantan, Gorontalo, Aceh, Central Java, South Sulawesi, and North Maluku), the availability of inclusive learning support for inclusive learning was not adequate. There has not a basic set of the curriculum yet designed specifically for students with learning disability. The most basic thing related to this aspect is the unavailability of a special syllabus for the learning of such students, which will serve as the basic framework in developing the plan and the learning process. The research results are similar to the research findings in inclusive schools in Samarinda. ${ }^{50}$

The research findings in inclusive schools in Samarinda are also similar with the research done by A.A. Ayu Sita Dewi Wijayanti, Piers Andreas Noak, Putu Eka Purnamaningsih in Bali. In their research, inclusion learning in public elementary school no. 11 Jimbaran used a modified regular school curriculum. In accordance with the research conducted by Hartanti Sulihandari in D.I Yogyakarta, the curriculum used in Senior High School 1 Sewon is The School-Based Curriculum

${ }^{50}$ Asep Supena, "Model Pendidikan Inklusif Untuk Siswa Tuna grahita di Sekolah Dasar", Jurnal Parameter Vol. 29, No. 2, 2017. 
with modifications that adjusted to the condition of the students. On the other hand, the research findings in inclusive schools in Samarinda are slightly different to the research done by Kamal Fuadi in DKI Jakarta. In his research, the curriculum used in the implementation of inclusive education programs was the curriculum used in regular schools, as learners with special needs learned in the same classroom as regular children who are not classified into special needs learners. ${ }^{51}$

Furthermore, based on research findings in inclusive schools in Samarinda, for the classroom management system, SD Bunga Bangsa Samarinda and SDN 016 Samarinda provided special classes for children with special needs, in SD Fastabiqul Khairat Samarinda children with special needs learned together in the same class with the regular student in the regular class. Each class was limited to about 2-5 students. Some children were handled by a special companion teacher. There were different types of special needs in one class. The sitting position in SD Fastabiqul Khairat Samarinda and SDN 016 Samarinda was already arranged by the homeroom teacher, while the sitting position in SD Bunga Bangsa Samarinda was flexible. Children with special needs were sitting in various sitting position, some of them were sitting in the back or in the front of the teacher with or without companion teacher. The sitting position was facing forward and sideways in random rows.

In the other hands, based on research findings in inclusive schools in Samarinda, the time allocation of Islamic Education lesson in the inclusion class at SD Fastabiqul Khairat Samarinda was $2 \times 35$ minutes once a week, at SD Bunga Bangsa Samarinda was $2 x 30$ minutes once a week, and at SDN 016 Samarinda was $3 \times 35$ minutes once a week. In the practice, the time allocation can be less than that, because the teacher has to face unexpected circumstances from the children with special needs.

According to the research conducted by Raudho Zaini in Medan, Islamic Education learning is only given 45 minutes in a week. Although learning is given for 45 minutes, the effective

51 Kamal Fuadi, "Analisis Kebijakan Penyelenggaraan Pendidikan Inklusif di Provinsi DKI Jakarta", Hikmah Journal Of Islamic Studies Vol. 11, No. 2, 2015. learning is only about 20 minutes. The research is similar to the research findings in inclusive schools in Samarinda. Therefore, the research findings in inclusive schools in Samarinda are different from the research by Rizali Hadi in Banjarmasin. In the research, the additional time allocation for Islamic religious education conducted by the principal and becomes very beneficial. Where the time allocation that should be three hours per week, it becomes four hours per week. This considerable time allows students to gain material enrichment. ${ }^{52}$

According to the research findings in inclusive schools in Samarinda, the learning materials of Islamic Education at SD Bunga Bangsa Samarinda and SDN 016 Samarinda were different from regular class, but the learning materials at SD Fastabiqul Khairat Samarinda is same as the regular students. Learning materials were related to the Quran, faith (akidah), worship (ibadah) and morals (akhlak). Some materials were the pillars of faith, the introduction about Allah, the angels (malaikat), good deeds, asmâ'ul husnâ, praiseworthy character, prayer, dhikr, the story of the prophets, loving animals, and caring for the environment. The teachers always connect the materials to the students' daily life.

According to Zuhairini, materials or teaching materials of Islamic Education covers the main knowledge of Islam, including: a). The matter of faith (akidah), b). The matter of Islam (syariah), and (c). The matter of ihsan (akhlak). These three core knowledge, then, are described in the form of pillars of faith, pillars of Islam and morals/ akhlak. These three things are emerging other knowledge: tawhîd or divinity, fiqih or Islamic law and akhlak or morals. Religious knowledge are then equipped with restrictions on the pillars of Islam and Islamic religious education materials namely: Quran and hadith, and added with the history of Islam (tarikh), so sequentially: (1) Tawhîd or divinity, (2) Fiqih or Islamic Law, (3) Quran, (4) Hadith, (5) Akhlak/Morals, (6) Tarîkh/ History. ${ }^{53}$ According to Abdul Rachman Shaleh,

52 Rizali Hadi, “Pembelajaran Pendidikan..., Tarbiyah Islamiyah Vol. 7, No. 2, July-December, 2017.

53 Zuhairini, dkk, Metodik Khusus Pendidikan Agama, (Surabaya: Usaha Nasional, 1981), pp. 60-61. 
in the preparation of the subject matter for designing curriculum of Religious education in the development school is done through such approaches: a. The human relationship with God, $b$. The relation between human beings, $c$. The human relationship with nature. ${ }^{54}$

Furthermore, based on research findings in inclusive schools in Samarinda, in teaching approach and method, Islamic Education teachers had strategies to pay more attention to children with special needs. There was no difference in teaching methods between regular children and special needs children at SD Fastabiqul Khairat Samarinda, while at SD Bunga Bangsa Samarinda and SDN 016 Samarinda the teachers used different methods to each child according to their type of special needs. The schools gave freedom to the teachers in determining the appropriate teaching methods. The teachers of SD Fastabiqul Khairat Samarinda could use Discussion Method and Demonstration Method. But they could not be applied in SD Bunga Bangsa Samarinda and SDN 016 Samarinda. Teaching methods of Islamic Education teachers were also varied. The approach used by the teachers at SD Fastabiqul Khairat Samarinda was Mixed Approach, while at SD Bunga Bangsa Samarinda and SDN 016 Samarinda, the teacher used individual approach.

According to the research findings in inclusive schools in Samarinda, in terms of teaching model, the teachers at SD Fastabiqul Khairat Samarinda applied Individual Learning, Direct Learning, Contextual Teaching and Learning and Cooperative Learning models. At SD Bunga Bangsa Samarinda and SDN 016 Samarinda, the teachers applied Direct Learning and Contextual Teaching and Learning. The implementation of Islamic Education teaching sequence from opening, main activities to closing is as follows: first, teacher starts with greetings, praying, checking student absence, then the teacher does ice breaking or intermezzo so that students feel comfortable to learn, the teacher reviews the previous material with question and answer, and the teacher delivers the main material. After learning, there are tasks and the teacher does the scoring as

${ }^{54}$ Abdul Rachman Shaleh, Pendidikan Agama \& Pembangunan Watak Bangsa, (Jakarta: Rajagrafindo Persada, 2005), p.6. rewards. After that, the teacher summarizes the lessons, makes students prepare for the next lesson, and closes the learning session by saying 'Hamdalah' then greetings. In addition, the activities outside Islamic Education class are reciting Quran with UMMI methods, memorizing the Quran, praying Dhuha and Dzuhur together, and doing the activities of ta'lim or listening to religious lectures. The primary goal of the teacher is to help the children with special needs to develop the their potentials, to help each individual to know themselves as unique human beings, and to help the students realize the potentials within them.

In the implementation of teaching in the inclusive schools, the teachers never impose children with special needs to follow the process in accordance with the planning that has been made by the teacher in the teaching planning or in curriculum documents. The primary goal of the teacher is to help the children with special needs to develop themselves. The teachers are fully responsible for understanding and getting to know children with special needs individually, so that the teachers can develop the ability of children with special needs in accordance with their potential. Although the students have limitations both in physical, learning, and psychological but they can have achievements in various ways like regular students. This is embodied in the concept of humanistic education. The humanistic approach regards learners as a whole person or a person as a whole. In other words, learning not only teaches the targeted materials but it also helps learners develop themselves as human beings. Learners' experiences are the foremost thing and their personal development and positive feelings are important in their learning. According to this approach, the teaching material must be seen as a totality that involves a whole person, not merely as a purely intellectual one. Like teachers, learners are people who have emotional, spiritual, or intellectual needs. ${ }^{55}$

55 Muhammad Yasin, "Teori Humanistik dalam Pembelajaran", in Jurnal AnNur, Vol.3 No.02 Juli-Desember 2016, pp. 52-53. 


\section{Conclusion}

The implementation of Islamic education teaching in inclusive schools in Samarinda requires several adjustments in teaching planning, implementation process, and learning evaluation. It has a Decision Letter (SK) as an inclusion school from the Ministry of Education. The screening process is done at the time of new students' admission. The teaching planning is prepared by the teachers referring to the regular curriculum and in the implementation has been modified in accordance with the ability of children with special needs. The schools are applying Curriculum of 2013 and the School-Based Curriculum. For the classroom management system, the inclusive schools provide a special class and regular class. The time allocation has a specific schedule. The learning materials are different to regular classes. The teaching models are direct learning and contextual teaching and learning. For learning evaluation, the teacher gives an evaluation; the oral and written questions, through a given worksheet, practices or daily habits assessment.

\section{References}

Darajat, Zakiah, Ilmu Jiwa Agama, Jakarta: Bulan Bintang, 1970.

Fuadi, Kamal, "Analisis Kebijakan Penyelenggaraan Pendidikan Inklusif di Provinsi DKI Jakarta", in Hikmah Journal Of Islamic Studies Vol. 11, No. 2, 2015.

Harms, Ernest, The Development of Religious Experience in Children, Chicago: The University of Chicago Press, 1994.

Hermawati, Penerapan Model Pembelajaran Agama Islam Bagi Anak Berkebutuhan Khusus di Sekolah Dasar Negeri 016 Kecamatan Sungai Kunjang Kota Samarinda, Samarinda: Institut Agama Islam Negeri, 2015.

Kementerian Agama Republik Indonesia, "Kemenag Siapkan Bahan Ajar PAI Untuk Anak Berkebutuhan Khusus", in https://www2. kemenag.go.id/berita/152833/ kemenag-siapkanbahan-ajar-pai-untuk- anak-berkebutuhankhusus, accessed February 4, 2018.

Kementerian Pendidikan dan Kebudayaan, "Sekolah Inklusi dan Pembangunan SLB Dukung Pendidikan Inklusi", in https://www. kemdikbud.go.id/main/blog/2017/02/sekolahinklusi-dan-pembangunan- slb-dukungpendidikan-inklusi, accessed March 27, 2018. Kurniasari, Desi, Evaluasi Program Pembelajaran PAl Pada Pendidikan Inklusif di Sekolah Menengah Al Firdaus Sukoharjo, Surakarta: IAIN Surakarta, 2017.

Marzuenda, Pelaksanaan Pembelajaran Pendidikan Agama Islam di Sekolah Luar Biasa Sri Mujinab Pekanbaru, Pekanbaru: Universitas Islam Negeri Sultan Syarif Kasim, 2013.

Mayasari, Implementasi Kurikulum 2013 Pada Anak Berkebutuhan Khusus (ABK) di SD Muhammadiyah Sapen Yogyakarta, Yogyakarta: Universitas Islam Negeri Sunan Kalijaga, 2016. Miles dan Huberman, Analisis Data Kualitatif, Jakarta: Universitas Indonesia Press, 1992.

Muhaimin, Paradigma Pendidikan Islam, Bandung: Remaja Rosdakarya, 1996.

Nurussalihah, Alfin, Implementasi Pembelajaran Pendidikan Agama Islam Terhadap Anak Berkebutuhan Khusus di Sekolah Inklusi Studi Multisitus di SDN Mojorejo 01 dan SDN Junrejo 01 Kota Batu, Malang: Universitas Islam Negeri Maulana Malik Ibrahim, 2016.

Pemerintah Provinsi Kalimantan Timur Dinas Pendidikan dan Kebudayaan, "Rekap Data Jumlah Sekolah Data Juni 2014", in http:// disdik.kaltimprov.go.id/pages/statis/28/rekapdata-jumlah-sekolah.html, accessed March 25, 2018.

Rachman Shaleh, Abdul, Pendidikan Agama \& Pembangunan Watak Bangsa, Jakarta: Rajagrafindo Persada, 2005.

Supena, Asep, “Model Pendidikan Inklusif Untuk Siswa Tunagrahita Di Sekolah Dasar", in Jurnal Parameter Vol. 29, No. 2, 2017.

Yasin, Muhammad, "Teori Humanistik Dalam Pembelajaran", Jurnal An Nur Vol.3, No.02 July-December, 2016.

Zaini, Raudho, Implementasi Pembelajaran Pendidikan Agama Islam Pada Anak Berkebutuhan Khusus di SekolahAlam Medan, Medan: Institut Agama Islam Negeri Sumatera Utara, 2013.

Zuhairini, dkk, Metodik Khusus Pendidikan Agama, Surabaya: Usaha Nasional, 1981. 